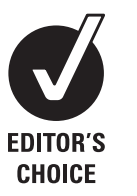

See Editorial, p 269

${ }^{1}$ Manchester Heart Centre, Manchester Royal Infirmary, Biomedical Research Centre, Manchester, UK

${ }^{2}$ Manchester Academic Health Science Centre, University of Manchester, Manchester, UK ${ }^{3}$ University Hospital of North Staffordshire, Stoke-on-Trent, UK

${ }^{4}$ Worcestershire Royal Hospital, Worcester, UK

${ }^{5}$ Institute Cardiovasculaire Paris Sud, Institut Hospitalier Jacquer Cartier, Massy, France

\section{Correspondence to} Dr Mamas A Mamas, Clinical Lecturer in Cardiology, Manchester Heart Centre, Manchester Royal Infirmary. Manchester M13 9PT, UK; mamasmamas1@yahoo.co.uk

MAM and KR are joint first authors who contributed equally to the manuscript.

Accepted 3 November 2011 Published Online First 6 December 2011

\title{
Influence of access site selection on PCl-related adverse events in patients with STEMI: meta-analysis of randomised controlled trials
}

\author{
Mamas A Mamas, ${ }^{1,2}$ Karim Ratib, ${ }^{3}$ Helen Routledge, ${ }^{4}$ Farzin Fath-Ordoubadi, ${ }^{1}$ \\ Ludwig Neyses, ${ }^{1,2}$ Yves Louvard, ${ }^{5}$ Douglas G Fraser, ${ }^{1}$ Jim Nolan ${ }^{3}$
}

\begin{abstract}
Objective A meta-analysis of all randomised controlled studies that compare outcomes of transradial versus the transfemoral route to better define best practice in patients with ST elevation myocardial infarction (STEMI). Design A Medline and Embase search was conducted using the search terms 'transradial,' 'radial', 'STEMI', 'myocardial' and 'infarction'.

Setting Randomised controlled studies that compare outcomes of transradial versus the transfemoral route. Patients A total of nine studies were identified that consisted of 2977 patients with STEMI.

Interventions Studies that compare outcomes of transradial versus the transfemoral route.

Main outcome measures The primary clinical outcomes of interest were (1) mortality; (2) major adverse cardiac events (MACE); (3) major bleeding and (4) access site complications
\end{abstract}

Results Transradial PCl was associated with a reduction in mortality (OR $0.53,95 \% \mathrm{Cl} 0.33$ to $0.84 ; \mathrm{p}=0.008$ ), MACE (OR 0.62, 95\% Cl 0.43 to 0.90; $p=0.012$ ), major bleeding events (OR 0.63, 95\% $\mathrm{Cl} 0.35-1.12 ; \mathrm{p}=0.12$ ) and access site complications (OR 0.30, 95\% Cl 0.19 to $0.48 ; p<0.0001)$ compared with procedures performed through the femoral route.

Conclusions This meta-analysis demonstrates a significant reduction in mortality, MACE and major access site complications associated with the transradial access site in STEMI. The meta-analysis supports the preferential use of radial access for STEMI PCI.

\section{INTRODUCTION}

Peri-procedural bleeding complications following percutaneous coronary intervention (PCI) are common and occur in up to $5 \%$ of cases performed in patients presenting with acute coronary syndromes (ACS). ${ }^{12}$ This procedure-related bleeding is independently associated with adverse events including 30-day mortality, reinfarction and stroke (cerebrovascular accident). ${ }^{2-6}$ Indeed, major bleeding was a more powerful predictor of mortality than peri-procedural myocardial infarction (MI) after PCI in the REPLACE- 2 trial. ${ }^{7}$ Clinical trials evaluating new pharmacological strategies have focused on reducing this bleeding risk, ${ }^{2}{ }^{8-10}$ although the benefits are often relatively modest. A significant proportion of major bleeding is related to the access site $^{11}$ and the transradial approach has been shown to reduce access site bleeding complications $^{5}$ and the requirement for blood transfusion $^{12}{ }^{13}$ in observational and randomised controlled trials. More recently, promising trends in mortality reduction have been found in observational studies. ${ }^{12} 14$

Patients with ST elevation myocardial infarction (STEMI) undergoing PCI are at the highest risk for the development of such bleeding complications. Data from the National Heart, Lung and Blood Institute Dynamic Registry have documented an independent fourfold increase in in-hospital mortality in patients presenting with STEMI compared with those with non-STEMI as well as greater access site bleeding complications requiring blood transfusion (3.3\% vs $2.1 \%) .{ }^{15}$ As STEMI represents the highest bleeding risk in the spectrum of ACS, these data have led some interventionists to recommend that radial access is employed as the primary access site in patients with STEMI as this cohort represents the highest bleeding risk in the spectrum of ACS. ${ }^{16}$ In contrast, this view is contested by other commentators, who argue that the enthusiasm for the transradial approach in patients with STEMI is not sufficiently justified by the evidence to support such a move towards its use. ${ }^{17}$

Although a previous meta-analysis of outcomes in patients with STEMI related to access site suggested benefits related to the use of radial access, many of the enrolled studies had a suboptimal (and often non-randomised) design. ${ }^{18}$ Recent publication of the RIVAL study ${ }^{19}$ has provided substantial new data derived from subgroup analysis on access sitemediated outcomes in patients with STEMI. When added to previous randomised trials the combined data may provides the current best available information on the influence of access site selection on outcome for patients with STEMI and may provide further insight into the controversy surrounding optimal access site choice for STEMI PCI. We, therefore, performed a meta-analysis in patients with STEMI undergoing PCI, analysing all randomised controlled studies that compared the impact of access site selection on mortality, major adverse cardiac events (MACE), major bleeding and access site complications to better define best practice in this high-risk group.

\section{METHODS}

This study was performed according to guidelines for preferred reporting for systematic reviews and 
meta-analyses (PRISMA) ${ }^{20}$ A Medline and Embase search (1990 to September 2011) was performed using the search terms 'transradial', 'radial', 'STEMI', 'myocardial' and 'infarction'. References and review articles were further scrutinised to ensure that all relevant studies were identified (figure 1). Only randomised controlled studies comparing outcomes after PCI in patients with STEMI between the radial versus the femoral access site were included in our analysis. STEMI within these studies comprised of primary PCI, rescue PCI and facilitated PCI. The primary clinical outcomes of interest, evaluated at the longest available follow-up, were (1) mortality; (2) MACE (according to study definitions); (3) major bleeding (according to study definition) and (4) access site complications.

\section{Statistical analysis}

All trials included in this meta-analysis were prospective, randomised controlled trials and publication level data were used for

\section{EMBASE and MEDLINE search: \\ Radial artery OR transradial AND myocardial infarction Years: 1990 to April 2011}

813 Articles

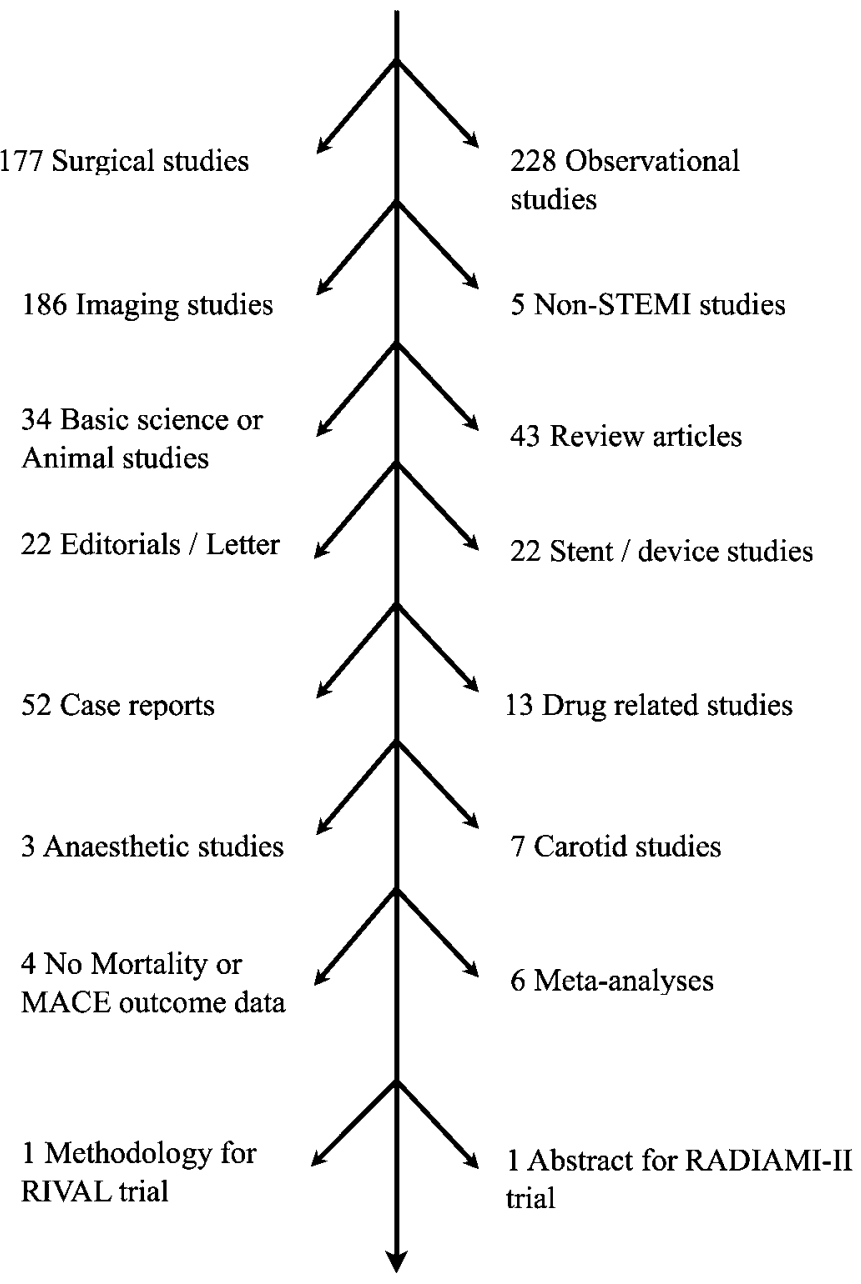

9 Randomised controlled trials 2977 patients

Figure 1 Search strategy for the studies. the analysis. For individual trials, the $\chi^{2}$ heterogeneity test was used to calculate the significance, OR and 95\% CIs for the differences in outcome between radial and femoral access in patients with STEMI. The treatment received was clearly shown for all trials and analysis was performed on the basis of the intention to treat. We used the Cochran $\mathrm{Q}$ test to assess heterogeneity across trials. Also, we calculated the $\mathrm{I}^{2}$ statistic to measure the consistency between trials with values of $25 \%, 50 \%$ and $75 \%$ defining the cut-off points for identifying low, moderate and high degrees of heterogeneity respectively. ${ }^{21}$ Treatment effects from individual trials were pooled using the random-effects DerSimonian and Laird model. The likelihood of publication or 'small-study' bias was assessed graphically by generating a funnel plot for the primary end point of MACE and by means of Egger's test. Exploratory meta-regression analyses were performed to assess the interaction of covariates, including proportion of primary PCI cases in each study, year of publication and percentage crossover rates on the OR for mortality of transradial versus transfemoral PCI in the setting of STEMI. A random-effects model of regression using the method of moments estimator was used for the meta-regression analysis. Data were analysed using Comprehensive Meta-analysis (version 2.0, Engelwood, New Jersey, USA).

\section{RESULTS}

A total of nine studies, dating from 2003 to 2011, were identified that fulfilled the search criteria: RIVAL, ${ }^{19}$ TEMPURA, ${ }^{22}$ RADIAL-AMI, ${ }^{23}$ FARMI, ${ }^{24}$ Yan et al, ${ }^{25}$ RADIAMI ${ }^{26}$ Gan et al, ${ }^{27}$ Hou et al, ${ }^{28}$ RADIAMI II, ${ }^{29}$ consisting of 2977 patients with STEMI. A summary of the studies included in this analysis including patient numbers, exclusion criteria, antiplatelet/anticoagulant protocols and operator experience in transradial $\mathrm{PCI}$ is presented in table 1. Baseline characteristics were evenly distributed between the two treatment groups in all trials. An overview of the defined end points is presented in table 2 and outcomes are presented in table 3 .

The mortality end point was reached in 28/1460 individuals in the radial group and 54/1517 in the femoral group. Meta-analysis of these data demonstrated an OR of 0.53 (95\% CI $0.33-0.84$; $\mathrm{p}=0.006$ ) for mortality in favour of the radial group (figure $2 \mathrm{~A}$ ). There appeared to be no heterogeneity among studies $(\mathrm{Q}=2.39$; $\left.\mathrm{p}=0.94, \mathrm{I}^{2}=0\right)$. A funnel plot of studies included in the metaanalysis of mortality data to assess for publication bias is presented in figure 2B. Studies were symmetrically distributed, indicating the absence of publication bias, confirmed by means of a negative Egger's test $(p=0.20)$.

Even after removal of the largest study, RIVAL from the dataset and repeating the meta-analysis a similar magnitude in reduction of mortality was seen, although this was not statistically significant (OR 0.71, 95\% CI 0.37-1.37, p=0.31). Furthermore, exploratory meta-regression analyses disclosed no statistically significant association between either proportion of patients who were primary PCI cases in each study $(p=0.76)$, year of publication $(p=0.38)$ or percentage crossover rates $(p=0.46)$ and mortality OR outcomes.

A total of 47/1461 MACE occurred in the radial group and 77/ 1508 in the femoral group. Figure 3 illustrates the Forrest plot after meta-analysis of MACE (OR $0.62,95 \%$ CI 0.43 to 0.90 ; $\mathrm{p}=0.012)$. Similarly no heterogeneity between studies was documented $\left(\mathrm{Q}=2.13 ; \mathrm{p}=0.98, \mathrm{I}^{2}=0\right)$.

Analysis of major bleeding events as defined by the individual studies themselves showed $18 / 1435$ events in the radial group and $33 / 1492$ events in the femoral group (OR $0.63,95 \% \mathrm{CI}$ 
Table 1 Summary of the studies included in meta-analysis

\begin{tabular}{|c|c|c|c|c|c|c|}
\hline $\begin{array}{l}\text { Studies } \\
\text { (year) }\end{array}$ & Number & $\begin{array}{l}\text { Single centre/ } \\
\text { multi centre }\end{array}$ & Exclusion criteria & STEMI cohort & $\begin{array}{l}\text { Anticoagulant/antiplatelet } \\
\text { protocol }\end{array}$ & $\begin{array}{l}\text { Operator radial experience } \\
\text { for participation in study }\end{array}$ \\
\hline TEMPURA (2003) & 149 & Single centre & $\begin{array}{l}\text { Thrombolysis, cardiogenic } \\
\text { shock with weak radial } \\
\text { pulse, abnormal Allen's } \\
\text { test, occluded SVG grafts, } \\
\text { culprit artery considered } \\
\text { not suitable for PCI because } \\
\text { of extreme tortuosity and/or } \\
\text { calcification proximally or } \\
\text { vessel size }<2.5 \mathrm{~mm} \text { in } \\
\text { diameter by visual estimate }\end{array}$ & Primary PCI 100\% & $\begin{array}{l}5000 / 6000 \text { units of heparin } \\
\text { given for female/male patients, } \\
\text { respectively. Oral administration } \\
\text { of aspirin of } 162 \mathrm{mg} \text { or more } \\
\text { and ticlopidine of } 200 \mathrm{mg} \text { daily } \\
\text { were started as soon as possible } \\
\text { after stent implantation and } \\
\text { continued for more than } 4 \text { weeks }\end{array}$ & Not available \\
\hline RADIAL-AMI (2005) & 50 & Multicentre & $\begin{array}{l}\text { Cardiogenic shock, abnormal } \\
\text { Allen's test result, or } \\
\text { contraindication to GP } \\
\text { Ilb/llla inhibitor }\end{array}$ & $\begin{array}{l}\text { Primary } \mathrm{PCl} 34 \% \\
\text { Rescue } \mathrm{PCl} 66 \%\end{array}$ & $\begin{array}{l}\text { Heparin (target activated clotting } \\
\text { time, } 200-300 \mathrm{~s} \text { ), aspirin } \\
\text { ( } 325 \mathrm{mg} \text { before the procedure) } \\
\text { and clopidogrel ( } 300 \mathrm{mg} \text { loading } \\
\text { dose, } 75 \mathrm{mg} \text { daily for a minimum } \\
\text { of } 28 \text { days after the procedure). } \\
\text { Abciximab (a bolus of } 0.25 \mathrm{mg} / \mathrm{kg} \\
\text { before or during procedure } \\
\text { followed by an infusion of } \\
0.125 \mathrm{microg} / \mathrm{kg} / \mathrm{min} \text { (maximum of } \\
10 \mu \mathrm{g} / \mathrm{min}) \text { ) for } 12 \mathrm{~h} \text { after } \mathrm{PCl}\end{array}$ & $\begin{array}{l}\text { Required to have performed } \\
\text { minimum of } 100 \text { transradial } \\
\mathrm{PCI} \text { procedures before study }\end{array}$ \\
\hline FARMI (2007) & 114 & Single centre & $\begin{array}{l}\text { History of CABG, } \\
\text { cardiogenic shock, } \\
\text { atrioventricular block } \\
\text { and contraindication to } \\
\text { abciximab or an abnormal } \\
\text { Allen's test }\end{array}$ & $\begin{array}{l}\text { Primary PCI } 50.9 \% \\
\text { Rescue } \mathrm{PCI} 42.1 \% \\
\text { Facilitated } \mathrm{PCI} 7 \%\end{array}$ & $\begin{array}{l}\text { IV bolus heparin (unfractionated } \\
\text { heparin } 50 \mathrm{IU} / \mathrm{kg} \text { or low molecular } \\
\text { weight heparin (enoxaparin) } 30 \mathrm{mg} \\
\mathrm{IV} \text { and } 1 \mathrm{mg} / \mathrm{kg} \text { subcutaneously) } \\
\text { and a bolus of aspirin ( } 250 \mathrm{mg} \mathrm{IV} \text { ). } \\
\text { During } \mathrm{PCl} \text { abciximab given (0.25 } \\
\mathrm{mg} / \mathrm{kg} \text { bolus followed by } 0.125 \\
\text { micrograms } / \mathrm{kg} / \mathrm{min} \text { infusion } \\
\text { during } 12 \mathrm{~h} \text { ). } \\
\text { Clopidogrel ( } 300 \mathrm{mg} \text { ), followed } \\
\text { by } 75 \mathrm{mg} \mathrm{daily} \mathrm{for} 1 \text { year, plus } \\
75-300 \mathrm{mg} / \text { day oral aspirin }\end{array}$ & $\begin{array}{l}\text { Required to have undertaken } \\
\text { more than } 100 \text { previous } \\
\text { successful transradial } \\
\text { coronary procedures }\end{array}$ \\
\hline Yan et al (2008) & 103 & Single centre & $\begin{array}{l}\text { Cardiogenic shock, } \\
\text { non-palpable radial artery, } \\
\text { abnormal Allen's test and } \\
\text { chronic renal failure }\end{array}$ & Primary $\mathrm{PCl} 100 \%$ & $\begin{array}{l}\text { All patients loaded with } \\
\text { clopidogrel } 600 \mathrm{mg} \text { and aspirin } \\
300 \mathrm{mg} \text { after the diagnosis of } \\
\text { AMI established. Tirofiban } \\
\text { administered with } 10 \mu \mathrm{g} / \mathrm{kg} \\
\text { bolus IV for } 3 \mathrm{~min} \text { followed by } \\
0.15 \mathrm{micrograms} / \mathrm{kg} / \mathrm{min} \text { infusion } \\
\text { for } 24 \mathrm{~h} \text {. During } \mathrm{PCl} \text {, patients } \\
\text { received a bolus of heparin } \\
\text { (70 U/kg) then received another } \\
2000-5000 \mathrm{U} \text { heparin every } \\
\text { hour during the procedure. } \\
\text { After PCl, patients given } \\
\text { clopidogrel } 75 \mathrm{mg} / \text { day for } 1 \text { year, } \\
\text { aspirin } 100-200 \mathrm{mg} / \text { day for life } \\
\text { and subcutaneous fragmin } 5000 \mathrm{U} \\
\text { twice daily for at least } 5-7 \text { days }\end{array}$ & $\begin{array}{l}\text { No formal entry requirements } \\
\text { but the operators were } \\
\text { interventional cardiologists } \\
\text { who had performed over } \\
500 \text { cases of transradial PCI }\end{array}$ \\
\hline RADIAMI (2009) & 100 & Single centre & $\begin{array}{l}\text { Age }>75 \text { years, Killip } \\
\text { class III or IV, intra-aortic } \\
\text { balloon pump placement } \\
\text { before the angiogram, height } \\
<150 \mathrm{~cm} \text {, history of CABG, } \\
\text { if the infarction may be due } \\
\text { to occluded bypass graft }\end{array}$ & Primary PCI 100\% & $\begin{array}{l}\text { All patients received heparin } \\
(70 \mathrm{U} / \mathrm{kg}) \text {, and } \mathrm{GP} \text { Ilb/llla receptor } \\
\text { blockers were administered during } \\
\text { the } \mathrm{PCl} \text {. Heparin administration } \\
\text { was continued after the } \\
\text { intervention only in the presence } \\
\text { of clinical indications }\end{array}$ & $\begin{array}{l}\text { No formal entry requirements } \\
\text { but operators performed at } \\
\text { least } 50-100 \text { transradial } \\
\text { PCI cases previously }\end{array}$ \\
\hline Gan et al (2009) & 195 & Multicentre & Abnormal Allen's test & Primary PCI 100\% & $\begin{array}{l}\text { All patients loaded with } 300 \mathrm{mg} \\
\text { aspirin and } 300 \mathrm{mg} \text { clopidogrel } \\
\text { as soon as they were diagnosed } \\
\text { as having an AMI. Heparin } \\
\text { administered at } 100 \mathrm{IU} / \mathrm{kg} \text {. } \\
\text { GP Ilb/llla inhibitors were } \\
\text { administered according to } \\
\text { the operator's discretion }\end{array}$ & Not available \\
\hline Hou et al (2010) & 200 & Single centre & $\begin{array}{l}\text { Cardiogenic shock, history } \\
\text { of coronary bypass graft, } \\
\text { Abnormal Allen's test and } \\
\text { non-palpable radial artery }\end{array}$ & Primary PCI 100\% & $\begin{array}{l}\text { All patients received aspirin } \\
\text { ( } 300 \mathrm{mg}) \text { and clopidogrel } \\
(300 \mathrm{mg}) \text { once diagnosis of } \\
\text { AMI was made. Fragmin } \\
5000 \mathrm{U} \text { s/c was used and } \\
\mathrm{GP} \mathrm{Ilb/llla} \mathrm{inhibitors} \mathrm{were} \\
\text { administered according to } \\
\text { the operator's discretion }\end{array}$ & $\begin{array}{l}\text { At least } 200 \text { transradial } \\
\text { PCl cases previously }\end{array}$ \\
\hline
\end{tabular}


Table 1 Continued

\begin{tabular}{|c|c|c|c|c|c|c|}
\hline $\begin{array}{l}\text { Studies } \\
\text { (year) }\end{array}$ & Number & $\begin{array}{l}\text { Single centre/ } \\
\text { multi centre }\end{array}$ & Exclusion criteria & STEMI cohort & $\begin{array}{l}\text { Anticoagulant/antiplatelet } \\
\text { protocol }\end{array}$ & $\begin{array}{l}\text { Operator radial experience } \\
\text { for participation in study }\end{array}$ \\
\hline RIVAL (2011) & 1958 & Multicentre & $\begin{array}{l}\text { Cardiogenic shock, severe } \\
\text { peripheral vascular disease } \\
\text { precluding a femoral } \\
\text { approach, or previous } \\
\text { coronary bypass surgery } \\
\text { with use of more than one } \\
\text { internal mammary artery }\end{array}$ & $\begin{array}{l}\text { Primary PCI } 74 \% \\
\text { Rescue PCI } 12 \% \\
\text { Facilitated PCI } 3 \% \\
\text { Other } 11 \%\end{array}$ & $\begin{array}{l}\text { Antithrombotic regimen } \\
\text { (including GP Ilb/llla inhibitors) } \\
\text { used for PCI was at the } \\
\text { discretion of the treating doctor }\end{array}$ & $\begin{array}{l}\text { At least } 50 \text { radial procedures } \\
\text { for coronary angiography or } \\
\mathrm{PCI} \text { within the previous year }\end{array}$ \\
\hline
\end{tabular}

ACT, activated clotting time; AMl, acute myocardial infarction; CABG, coronary artery bypass grafting; GP, glycoprotein; STEMI, ST elevation myocardial infarction; SVG, saphenous vein grafts; TFA, transfemoral approach; TRA, transradial approach.

$0.35-1.12 ; \mathrm{p}=0.12$; figure $4 \mathrm{~A}$. No heterogeneity between studies was detected; $\left.Q=3.82, p=0.80, I^{2}=0\right)$. After removal of the largest study, RIVAL from the dataset and repeating the metaanalysis an even greater magnitude in reduction of major bleeding (OR 0.50, 95\% CI 0.24-1.04, $\mathrm{p}=0.062$ ) was found.

Finally, access site complications were meta-analysed with a significant reduction in access site complications seen in the radial group (OR $0.30,95 \%$ CI 0.19 to 0.48 ; $p<0.0001$; figure $4 \mathrm{~B}$ ), which remained significantly reduced even if RIVAL was removed from the analysis (OR $0.25,95 \%$ CI 0.13 to 0.50 ; $\mathrm{p}<0.0001)$.

\section{DISCUSSION}

Radial access was reintroduced into clinical practice just over 20 years ago and used for PCI shortly after. Over this time period extensive data have accumulated confirming that the technique is preferred by patients, reduces procedural costs, may protect against renal complications such as contrast-induced nephropathy ${ }^{30}$ and access site complication rates. Technical and procedural innovations have progressively improved the applicability of the technique. In this meta-analysis of nine randomised studies consisting of 2977 patients we demonstrate that adoption of the transradial route for PCI in patients with STEMI is associated with a $48 \%$ reduction in the risk of mortality in comparison with procedures performed through the femoral route. This is in agreement with a previous meta-analysis of pooled randomised and prospective and retrospective observational studies including 12 studies and 3324 patients with STEMI, ${ }^{18}$ which also demonstrated a $46 \%$ reduction in mortality.

Observational studies such as the MORTAL study (Mortality benefit Of Reduced Transfusion after PCI via the Arm or Leg) in which over 32000 PCI procedures were analysed have similarly demonstrated that PCI performed through the transradial route is independently associated with a reduction in mortality in comparison with procedures performed through the femoral route. ${ }^{12}$ Similarly, in a large retrospective observational study involving 1051 patients admitted with STEMI, in-hospital mortality in the femoral group was approximately double that recorded in the radial group. ${ }^{31}$ When data were analysed by the actual site of access, significantly greater major access site complications were recorded in the femoral group than in the radial group $(1.9 \%$ vs $0 \%, p=0.001)$. Other retrospective studies have also demonstrated both a decrease in mortality and a reduction in major bleeding complications in patients with
STEMI undergoing PCI through the transradial route in comparison with the femoral access site. ${ }^{32}$

Both large randomised controlled studies and numerous elective and ACS registries have demonstrated that major bleeding and transfusion after PCI are associated with increased inhospital and 1-year mortality. ${ }^{2-6}$ For example, in the MORTAL study, blood transfusion was independently associated with fourfold increase in 30-day mortality (95\% CI 3.08 to 5.22 ). ${ }^{12}$ Furthermore, previous studies with treatments that reduce the risk of bleeding but retain efficacy similar to that of standard treatment have shown reductions in mortality in ACS, ${ }^{9} 1033$ thereby suggesting a causative link between major bleeding and death. In the MORTAL study, transradial access reduced blood transfusions by $50 \%$ with an associated mortality benefit. ${ }^{12}$

In our meta-analysis we have also demonstrated that the decrease in mortality was associated with a parallel reduction in major access site complications (OR 0.30, 95\% CI 0.19 to 0.48 ; $\mathrm{p}<0.0001)$ and trend towards a reduction in major bleeding (OR 0.63, 95\% CI 0.35-1.12; $\mathrm{p}=0.12$ ). Other studies have similarly shown a reduction in both bleeding and access site complications associated with the transradial route. For example, analysis of over 500000 PCI procedures in the US national cardiovascular data registry showed a $58 \%$ reduction in bleeding (OR $0.42,95 \%$ CI 0.31 to 0.56 ) with an approximately 3.5 -fold decrease in vascular complications. ${ }^{4}$ Similarly, in a metaanalysis of 23 randomised studies, the transradial route was associated with a $73 \%$ reduction of major bleeding compared with the femoral route. ${ }^{13}$ When these data were combined with the recent RIVAL study, analysis of 10967 patients showed that major bleeding remained significantly reduced in those patients undergoing PCI through the transradial route (OR $0.5195 \% \mathrm{CI}$ 0.33 to $0.79 ; \mathrm{p}=0.002$ ).

Our meta-analysis demonstrated a trend towards a reduction in major bleeding (OR 0.63, 95\% CI 0.35-1.12; $\mathrm{p}=0.12$ ), although risk of major bleeding even if performed through the transradial route in the setting of STEMI still remain significant. The reasons for this are several fold. The use of transradial access does not eliminate all bleeding after PCI. Major bleeding complications comprise both access site and non-access site complications. Adoption of the transradial route would only be expected to reduce bleeding complications from the access site. In a post hoc analysis of the REPLACE-2, ACUITY and HORIZONS AMI trial involving 17393 patients, $61.4 \%$ of all recorded bleeds were not related to the access site,${ }^{11}$ hence the transradial approach would only be expected to affect the incidence of 
Table 2 Summary of study definitions

\begin{tabular}{|c|c|c|c|c|}
\hline Studies (Year) & Major bleeding definition & Minor bleeding definition & Access site complications & Primary end point \\
\hline TEMPURA (2003) & $\begin{array}{l}\text { Bleeding requiring blood } \\
\text { transfusion and/or surgical } \\
\text { repair or cerebral bleeding }\end{array}$ & Not defined & Not defined & MACE: TLR, repeat AMI or death \\
\hline RADIAL-AMI (2005) & $\begin{array}{l}\text { Intracranial or retroperitoneal } \\
\text { bleeding, a drop in } \\
\text { haemoglobin level }>5 \mathrm{~g} / \mathrm{dl} \text { or } \\
\text { haematocrit }>15 \% \text {, whole } \\
\text { blood or packed red cell } \\
\text { transfusions }\end{array}$ & Not defined & $\begin{array}{l}\text { Haematoma }>5 \mathrm{~cm} \text {, } \\
\text { pseudoaneurysm, arteriovenous } \\
\text { fistula, access site rebleeding } \\
\text { after initial haemostasis }\end{array}$ & $\begin{array}{l}\text { Primary efficacy end point: } \\
\text { reperfusion time. Primary safety } \\
\text { end point: major bleeding }\end{array}$ \\
\hline FARMI (2007) & $\begin{array}{l}\text { TIMI major bleeding involving } \\
\text { a haemoglobin drop of }>5 \mathrm{~g} / \mathrm{dl} \\
\text { or intracranial } \\
\text { haemorrhage or cardiac } \\
\text { tamponade }\end{array}$ & $\begin{array}{l}\text { TIMI minor bleeding: } \\
\text { haemoglobin drop }>3 \mathrm{~g} / \mathrm{dl} \\
\text { but }<5 \mathrm{~g} / \mathrm{dl} \text {, with bleeding } \\
\text { from a known site or } \\
\text { spontaneous gross haematuria, } \\
\text { haemoptysis or haematemesis }\end{array}$ & $\begin{array}{l}\text { False aneurysm, haematoma } \\
\text { (defined as local induration of } \\
>4 \mathrm{~cm} \text { diameter) and ecchymosis } \\
\text { (defined as cutaneous bruise or } \\
\text { induration of }<4 \mathrm{~cm} \text { ) }\end{array}$ & $\begin{array}{l}\text { Peripheral vascular complication } \\
\text { rates and } \mathrm{PCl} \text { efficiency and } \\
\text { tolerance of the procedure }\end{array}$ \\
\hline Yan et al (2008) & $\begin{array}{l}\text { Haemoglobin loss of at least } \\
2 \mathrm{mmol} / \mathrm{l} \text {, the administration } \\
\text { of a blood transfusion, } \\
\text { vascular repair, or prolonged } \\
\text { hospitalisation }\end{array}$ & $\begin{array}{l}\text { Haematoma formation not } \\
\text { requiring specific treatment }\end{array}$ & $\begin{array}{l}\text { Haematoma, pseudoaneurysm } \\
\text { and arterial occlusion }\end{array}$ & $\begin{array}{l}\text { Vascular access site complications } \\
\text { including minor bleeding } \\
\text { (haematoma), major bleeding, } \\
\text { pseudoaneurysm and artery } \\
\text { occlusion. MACE defined as death, } \\
\text { recurrent AMI and repeat target } \\
\text { vascular revascularisation }\end{array}$ \\
\hline RADIAMI (2009) & $\begin{array}{l}\text { Fatal bleeding, bleeding } \\
\text { requiring blood transfusion, } \\
\text { operation or resulting in a } \\
\text { drop of haemoglobin count } \\
\text { of }>3 \mathrm{~g} / \mathrm{dl} \text { as well as any } \\
\text { intracranial haemorrhage }\end{array}$ & $\begin{array}{l}\text { All bleeding complications that } \\
\text { did not fulfil criterion for major } \\
\text { bleeding complications defined } \\
\text { as minor }\end{array}$ & Not defined & Primary end point not defined \\
\hline Gan et al (2009) & $\begin{array}{l}\text { Not defined, although data } \\
\text { presented for major bleeding }\end{array}$ & Not defined & $\begin{array}{l}\text { Not defined, although data } \\
\text { presented for presence of and } \\
\text { type of vascular access site } \\
\text { complications }\end{array}$ & $\begin{array}{l}\text { Major adverse cardiac events, } \\
\text { including death, CABG, myocardial } \\
\text { infarction and target lesion } \\
\text { revascularisation }\end{array}$ \\
\hline Hou et al (2010) & $\begin{array}{l}\text { Haemoglobin loss of } \geq 2 \\
\mathrm{mmol} / \mathrm{l} \text { or administration of } \\
\text { blood transfusions }\end{array}$ & $\begin{array}{l}\text { Haematoma formation not } \\
\text { requiring specific treatment }\end{array}$ & Not defined & $\begin{array}{l}\text { MACE defined as death, recurrent } \\
\text { myocardial infarction, or target } \\
\text { vessel revascularisation }\end{array}$ \\
\hline RIVAL (2011) & $\begin{array}{l}\text { Fatal bleeding, transfusion of } \\
\text { two or more units of red } \\
\text { blood cells or equivalent } \\
\text { whole blood, bleeding causing } \\
\text { substantial hypotension with } \\
\text { the need for inotropes, } \\
\text { surgical intervention (only if } \\
\text { there has been substantial } \\
\text { hypotension or transfusion of } \\
\text { at least two units of blood), } \\
\text { bleeding causing severely } \\
\text { disabling sequelae, intracranial } \\
\text { bleeding and symptomatic or } \\
\text { intraocular leading to } \\
\text { significant visual loss }\end{array}$ & $\begin{array}{l}\text { Bleeding events that did not } \\
\text { meet the criteria for a major } \\
\text { bleed and required transfusion } \\
\text { of one unit of blood or } \\
\text { modification of the drug } \\
\text { regimen (ie, cessation of } \\
\text { antiplatelet or antithrombotic } \\
\text { treatment) }\end{array}$ & $\begin{array}{l}\text { Pseudoaneurysm needing } \\
\text { closure, large haematoma (as } \\
\text { judged by investigator), } \\
\text { arteriovenous fistula, or an } \\
\text { ischaemic limb needing surgery }\end{array}$ & $\begin{array}{l}\text { Primary end point composite of } \\
\text { death, AMI, stroke, or non- } \\
\text { CABG-related major bleeding } \\
\text { at } 30 \text { days }\end{array}$ \\
\hline RADIAMI II (2011) & $\begin{array}{l}\text { Fatal bleeding, bleeding } \\
\text { requiring blood transfusion, } \\
\text { operation or resulting in a } \\
\text { drop of haemoglobin count of } \\
>3 \mathrm{~g} / \mathrm{dl} \text { or any intracranial } \\
\text { haemorrhage }\end{array}$ & $\begin{array}{l}\text { Bleeding events that did not } \\
\text { meet the criteria for a } \\
\text { major bleed }\end{array}$ & Not defined & $\begin{array}{l}\text { Serious cardiac events including } \\
\text { repeat cardiac revascularisation } \\
\text { in the infarct-related artery, } \\
\text { new } C A B G \text {, new } M I \text { occurrence } \\
\text { and death from any cause }\end{array}$ \\
\hline
\end{tabular}

AMI, acute myocardial infarction; CABG, coronary artery bypass grafting; MACE, major adverse cardiac event; TIMI, thrombolysis in myocardial infarction; TLR, target lesion revascularisation.

$38.6 \%$ of these major bleeds. Similarly, in the RIVAL study, only $30 \%$ of all major bleeds not related to coronary artery bypass grafting (non-CABG) were related to the access site. ${ }^{19}$

The prognostic implications of non-access site-related bleeds are greater than those of access site-related bleeds, hence an intervention that reduces only the latter will have a smaller effect on mortality outcomes than an intervention influencing non-access site-related bleeding rates. For example, analysis of REPLACE-2, ACUITY and HORIZONS AMI studies showed that access site bleeds were independently associated with a 1.82 increase in 1-year mortality (95\% CI 1.17 to 2.83 ; $p=0.008$ ), whereas non-access site complications were associated with a 3.94 -fold increase in 1-year mortality (95\% CI 3.07 to 5.15; $\mathrm{p}<0.0001) .{ }^{11}$ These data suggest that PCI patients will benefit from the adoption of safest access site practice (use of the transradial approach) in combination with an antithrombotic regimen optimised to preserve anti-ischaemic efficacy but minimise systemic bleeding.

The mechanism by which radial access reduces mortality and MACE in patients with STEMI may be related to the prevention of both bleeding and access site complications. Large access site bleeds can lead to haemodynamic instability and blood transfusion with an associated range of deleterious consequences. Although these events are relatively infrequent, associated cardiovascular adverse events are common in these patients. Some access site complications will not result in substantial 


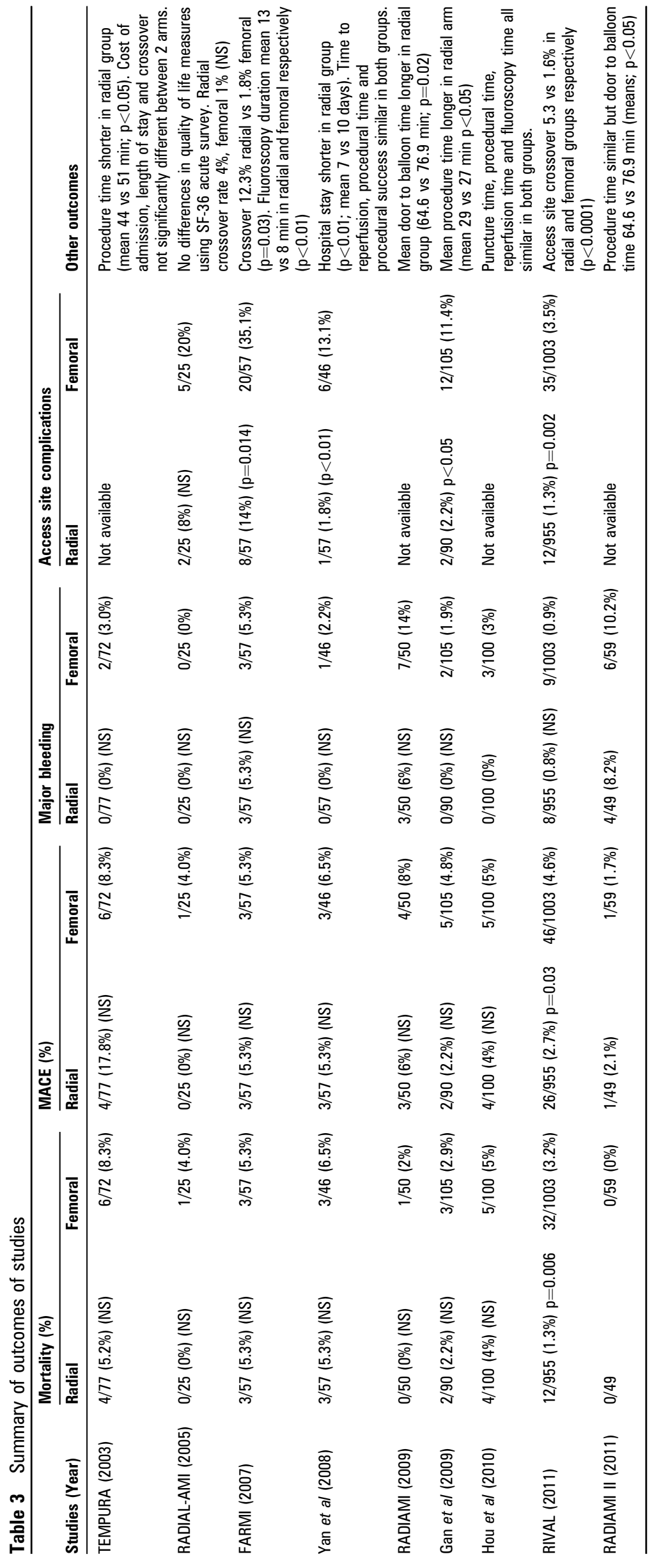


A

Study name $\quad$ OR $(95 \% \mathrm{CI}) \quad$ p-Value

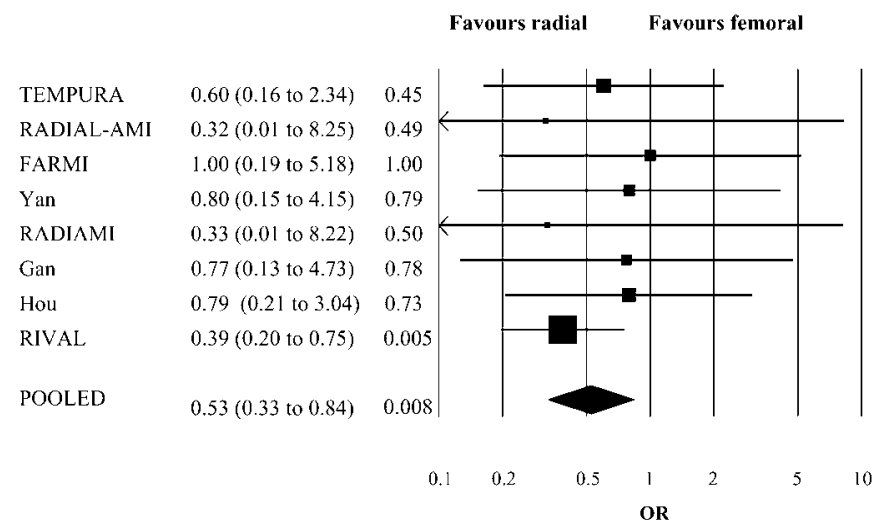

B

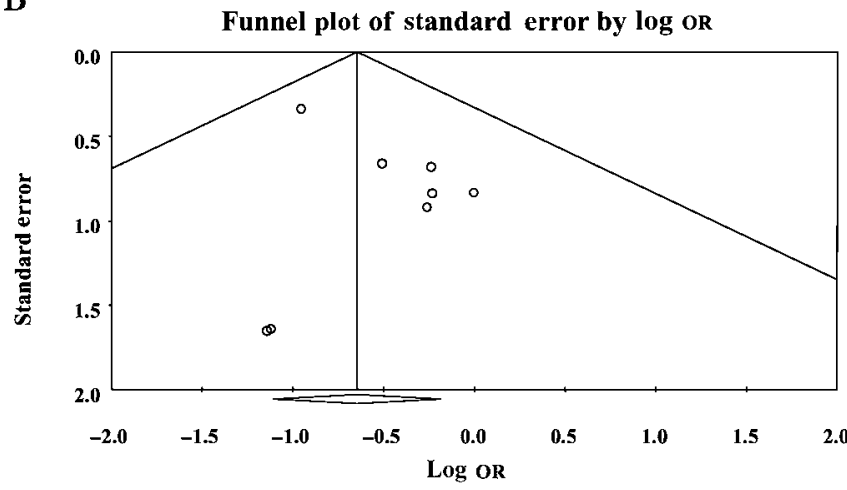

Figure 2 (A) Forest plot comparing mortality outcomes in the radial versus the femoral access site in randomised PCI trials in STEMI patients. Odds ratios $(\mathrm{OR})$ and $95 \%$ confidence intervals $(\mathrm{Cl})$ are presented for individual studies and pooled data. (B) Funnel plot of studies for mortality data.

blood loss but still require intervention with consequent activation of systemic inflammation and coagulation and compromised antiplatelet regimens. This results in a disproportionate risk of cardiovascular events even though the initial insult is not haemodynamically significant.

Study OR $(95 \% \mathrm{CI}) \quad$ p Value

Favours radial Favours femoral

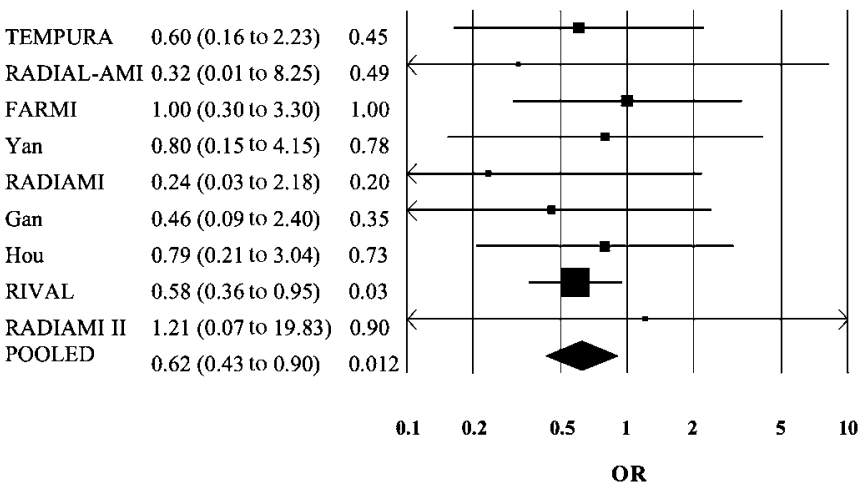

Figure 3 Forest plot comparing major adverse cardiac events outcomes in the radial versus the femoral access site in randomised $\mathrm{PCl}$ trials in patients with ST elevation myocardial infarction. ORs and $95 \%$ Cls are presented for individual studies and pooled data.
A Study name OR $(95 \% \mathrm{CI}) \quad$ p Value

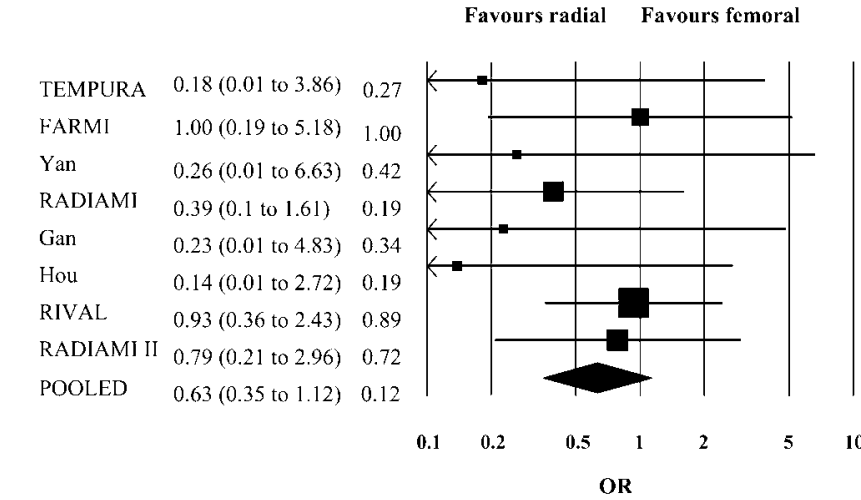

B Study name OR $(95 \%$ CI $) \quad$ p Value

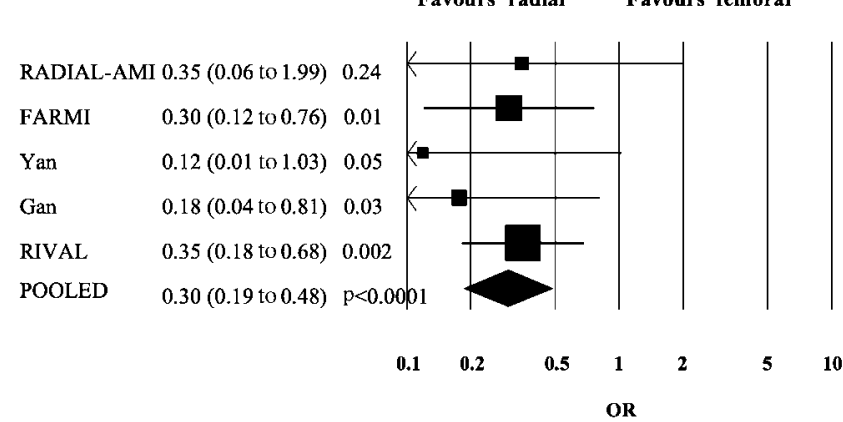

Figure 4 (A) Forrest plot comparing major bleeding outcomes in the radial versus the femoral access site in randomised $\mathrm{PCI}$ trials in patients with ST elevation myocardial infarction (STEMI). ORs and 95\% Cls are presented for individual studies and pooled data.

(B) Forrest plot comparing access site complication outcomes in the radial versus the femoral access site in randomised $\mathrm{PCI}$ trials in patients with STEMI. ORs and 95\% Cls are presented for individual studies and pooled data.

All of the studies contained in our meta-analysis were intention to treat and were associated with significant crossover rates of between $1.8 \%$ and $12 \%$. For example, in the largest study used in this analysis, the RIVAL study, the crossover rate was $7.6 \%$ and when access site major bleeds were analysed in the radial group, the location of these access site bleeds were found to be in the femoral access site only mainly due to crossover. $^{19}$

The definition of major bleeding used in individual studies may in itself influence the reported outcomes. For example, in the RIVAL study, ${ }^{19}$ while non-CABG related major bleeding as defined by the study (see table 2) showed a trend towards a reduction, although it was not statistically significant (OR $0.73,95 \%$ CI 0.43 to 1.23 ; $p=0.9$ ), use of the ACUITY major bleeding criterion was associated with a statistically significant reduction in major bleeding in the radial arm of study compared with the femoral arm (OR $0.4395 \%$ CI 0.32 to 0.57 ; $p<0.0001$ ). Furthermore, differing definitions of major bleeding will have different effects on outcome-for example, in pooled analysis of PURSUIT and PARAGON randomised controlled trials involving 15454 patients a stronger association between the GUSTO definition of major bleeding and 30-day death or MI (OR 5.57 $95 \%$ CI 4.33 to 7.17 ) than between TIMI major bleeding definition and 30-day death or MI was seen (OR 1.45, 95\% CI 1.23 to 1.70$){ }^{34}$ 
There is some evidence that operator and unit expertise plays a role in the relationship between radial access and the prevention of MACE. In RIVAL, the high-volume radial units had reduced MACE in all patients with ACS, not just those with STEMI. This suggests that adopting a high-volume radial programme will bring additional benefits to a wide range of patients. It is important to recognise that the radial approach is associated with an important learning curve. Before embarking on a transradial STEMI programme operators and institutions must develop their skills in less challenging patient populations. Studies included in this analysis had relatively modest requirements for transradial operator experience for participation-for example, several of the studies only required operators to have performed from 50 to 100 transradial procedures in total, ${ }^{19} 232426$ even though data have suggested that the learning curve for transradial procedures begins to plateau at around 1000 cases.

Our meta-analysis has a number of potential limitations. First, an inherent limitation of any meta-analysis is that of publication bias; studies that show a neutral outcome in mortality are less likely to be published than those that show a positive outcome and thus tend to bias any meta-analysis of published data towards a more positive outcome. However, our analysis for publication bias did not demonstrate the presence of this potential confounder. Second, the RIVAL study contributed $66 \%$ of all the patients analysed as part of this meta-analysis, hence it is possible that the larger RIVAL dataset may 'drive' the outcome of the pooled meta-analysis. To assess for this potential confounder, we repeated our analyses without the inclusion of the RIVAL dataset and found similar magnitudes of the end points, including mortality ( $47 \%$ reduction with inclusion of RIVAL, 39\% reduction without), major bleeding (37\% with inclusion of RIVAL, $50 \%$ reduction without) and access site complications $(70 \%$ with inclusion of RIVAL, $75 \%$ reduction without). Finally, although all the studies analysed included only patients with STEMI, these comprised patients presenting for primary PCI, rescue PCI and facilitated PCI, hence it is unclear whether individual analyses of these subgroups might have yielded different outcomes. However, exploratory meta-regression analysis of the largest subgroup of the STEMI cohort (primary PCI) did not show a statistically significant association between either the proportion of patients who were primary PCI cases in each study and the magnitude of outcomes.

In conclusion, in this meta-analysis of 9 studies including 2977 STEMI patients we have observed a significant reduction in mortality, major access site complications and a trend towards a reduction in major bleeding events. Primary PCI represents the 'gold standard' of care in the management of STEMI and these patients are at the highest risk for bleeding complications and mortality. It is therefore not surprising that reducing access siterelated bleeding complications has the potential to favourably affect mortality rates. Our meta-analysis must be considered to be hypothesis generating since no single adequately powered randomised controlled study has compared the influence of arterial access site selection on clinical outcomes in primary PCI patients. There is an urgent need for such a trial in view of the potential for radial access to reduce mortality and MACE. Until such a trial is available, our meta-analysis provides the best available data and supports the use of radial access for primary PCI reinforcing the view of earlier editorialists. ${ }^{35}$

\section{Competing interests None.}

Contributors All authors have contributed and fullfil the authorship guidelines. All authors have read the manuscript and approve its final submission.

Provenance and peer review Not commissioned; externally peer reviewed.

\section{REFERENCES}

1. Moscucci M, Fox KA, Cannon CP, et al. Predictors of major bleeding in acute coronary syndromes: the Global Registry of Acute Coronary Events (GRACE). Eur Heart J 2003;24:1815-23.

2. Budaj A, Eikelboom JW, Mehta SR, et al; OASIS 5 Investigators. Improving clinical outcomes by reducing bleeding in patients with non-ST-elevation acute coronary syndromes. Eur Heart J 2009;30:655-61.

3. Rao SV, Eikelboom JA, Granger CB, et al. Bleeding and blood transfusion issues in patients with non-ST-segment elevation acute coronary syndromes. Eur Heart J 2007;28:1193-204.

4. Rao SV, Ou FS, Wang TY, et al. Trends in the prevalence and outcomes of radial and femoral approaches to percutaneous coronary intervention: a report from the National Cardiovascular Data Registry. JACC Cardiovasc Interv 2008;1:379-86.

5. Manoukian SV, Feit F, Mehran R, et al. Impact of major bleeding on 30-day mortality and clinical outcomes in patients with acute coronary syndromes: an analysis from the ACUITY trial. J Am Coll Cardiol 2007;49:1362-8.

6. Yang $\mathbf{X}$, Alexander KP, Chen AY, et al. The implications of blood transfusions for patients with non-ST-segment elevation acute coronary syndromes: results from the CRUSADE National Quality Improvement Initiative. J Am Coll Cardiol 2005;:46:1490-5

7. Feit $\mathbf{F}$, Voeltz MD, Attubato MJ, et al. Predictors and impact of major hemorrhage on mortality following percutaneous coronary intervention from the REPLACE-2 Trial. Am J Cardiol 2007;100:1364-9.

8. Montalescot G, White HD, Gallo R, et al. Enoxaparin versus unfractionated heparin in elective percutaneous coronary intervention. N Engl J Med 2006;355:1006-17.

9. Cannon CP, Harrington RA, James S, et al; PLATelet inhibition and patient Outcomes Investigators. Comparison of ticagrelor with clopidogrel in patients with a planned invasive strategy for acute coronary syndromes (PLATO): a randomised double-blind study. Lancet 2010;375:283-93.

10. Mehran R, Lansky AJ, Witzenbichler B, et al; HORIZONS-AMI Trial Investigators. Bivalirudin in patients undergoing primary angioplasty for acute myocardial infarction (HORIZONS-AMI): 1-year results of a randomised controlled trial. Lancet 2009;374:1149-59.

11. Verheugt FW, Steinhubl SR, Hamon M, et al. Incidence, prognostic impact and influence of antithrombotic therapy on access and nonaccess site bleeding in percutaneous coronary intervention. JACC Cardiovasc Interv 2011:4:191-7.

12. Chase A, Fretz E, Warburton W, et al. Association of the arterial access site at angioplasty with transfusion and mortality: the M.O.R.T.A.L study (Mortality benefit Of Reduced Transfusion after percutaneous coronary intervention via the Arm or Leg). Heart 2008;94:1019-25.

13. Jolly SS, Amlani S, Hamon M, et al. Radial versus femoral access for coronary angiography or intervention and the impact on major bleeding and ischemic events: a systematic review and meta-analysis of randomized trials. Am Heart $\mathrm{J}$ 2009;157:132-40.

14. Pristipino C, Trani C, Nazzaro MS, et al; Prospective REgistry of Vascular Access in Interventions in Lazio Region Study Group. Major improvement of percutaneous cardiovascular procedure outcomes with radial artery catheterisation: results from the PREVAlL study. Heart 2009;95:476-82.

15. Abbott JD, Ahmed HN, Vlachos HA, et al. Comparison of outcome in patients with ST-elevation versus non-ST-elevation acute myocardial infarction treated with percutaneous coronary intervention (from the National Heart, Lung and Blood Institute Dynamic Registry). Am J Cardiol 2007;100:190-5.

16. Hamon M, Nolan J. Should radial artery access be the "gold standard" for PCI? Heart 2008;94:1530-2.

17. Patterson T, Foale RA. If the radial artery is the new standard of care in primary percutaneous coronary intervention, why is most intervention done by the femoral approach? Heart 2011;97:521-2.

18. Vorobcsuk A, Kónyi A, Aradi D, et al. Transradial versus transfemoral percutaneous coronary intervention in acute myocardial infarction Systematic overview and metaanalysis. Am Heart J 2009;158:814-21.

19. Jolly SS, Yusuf S, Cairns J, et al; for the RIVAL trial group. Radial versus femoral access for coronary angiography and intervention in patients with acute coronary syndromes (RIVAL): a randomised, parallel group, multicentre trial. Lancet 2011;377:1409-20

20. Liberati A, Altman DG, Tetzlaff J, et al. The PRISMA statement for reporting systematic reviews and meta-analyses of studies that evaluate healthcare interventions: explanation and elaboration. BMJ 2009;339:b2700.

21. Higgins JP, Thompson SG, Deeks JJ, et al. Measuring inconsistency in metaanalyses. BMJ 2003;327:557-60.

22. Saito S, Tanaka $S$, Hiroe $Y$, et al. Comparative study on transradial approach vs transfemoral approach in primary stent implantation for patients with acute myocardial infarction: results of the test for myocardial infarction by prospective unicenter randomization for access sites (TEMPURA) trial. Catheter Cardiovasc Interv 2003;59:26-33.

23. Cantor W, Puley G, Natarajan M, et al. Radial versus femoral access for emergen percutaneous coronary intervention with adjunct glycoprotein Ilb/lla inhibition in acute myocardial infarction-the RADIAL-AMI pilot randomized trial. Am Heart $J$ 2005; 150:543-9.

24. Brasselet C, Tassan S, Nazeyrollas P, et al. Randomised comparisonof femoral versus radial approach for percutaneous coronary intervention using abciximab in acute myocardial infarction: results of the FARMI trial. Heart 2007:93:1556-61. 
25. Yan Z, Zhou Y, Zhao Y, et al. Safety and feasibility of transradial approach for primary percutaneous coronary intervention in elderly patients with acute myocardial infarction. Chin Med J (Engl) 2008;121:782-6.

26. Chodor P, Krupa H, Kurek T, et al. Radial versus femoral approach for percutaneous coronary interventions in patients with acute myocardial infarction. (RADIAMI) A prospective randomized, single center clinical trial. Cardiol J 2009:16:332-40.

27. Gan L, Li Q, Liu R, et al. Effectiveness and feasibility of transradial approaches for primary percutaneous coronary intervention in patients with acute myocardial infarction. J Nanijing Med Univ 2009:23:270-4.

28. Hou L, Wei D, Li W, et al. Comparative study on transradial versus transfemoral approach for primary percutaneous coronary intervention in Chinese patients with acute myocardial infarction. Saudi Med J 2010;31:158-62.

29. Chodor P, Kurek T, Kowalczuk A, et al. Radial vs femoral approach with StarClose clip placement for primary percutaneous coronary intervention in patients with ST-elevation myocardial infarction. RADIAMI II: a prospective, randomised, single centre trial. Kardiol Pol 2011;69:763-71.

30. Vuurmans T, Byrne J, Fretz $\mathrm{E}$, et al. Chronic kidney injury in patients after cardiac catheterisation or percutaneous coronary intervention: a comparison of radial and femoral approaches (from the British Columbia Cardiac and Renal Registries). Heart 2010;96:1538-42.

31. Hetherington SL, Adam Z, Morley R, et al. Primary percutaneous coronary intervention for acute ST-segment elevation myocardial infarction: changing patterns of vascular access, radial versus femoral artery. Heart 2009;95: 1612-18.

32. Arzamendi $\mathbf{D}$, Ly HQ, Tanguay JF, et al. Effect on bleeding, time to revascularization and one-year clinical outcomes of the radial approach during primary percutaneous coronary intervention in patients with ST-segment elevation myocardial infarction. Am J Cardiol 2010;106:148-54.

33. Yusuf S, Mehta SR, Chrolavicius $S$, et al. Comparison of fondaparinux and enoxaparin in acute coronary syndromes. N Engl J Med 2006;354: 1464-76.

34. Rao SV, O'Grady K, Pieper KS, et al. A comparison of the clinical impact of bleeding measured by two different classifications among patients with acute coronary syndromes. J Am Coll Cardiol 2006;47:809-16.

35. Amoroso G, Kiemeneij F. Transradial access for primary percutaneous coronary intervention: the next standard of care? Heart 2010:96:1341-4.

\section{SAVE TIME AND KEEP INFORMED}

\section{heart}

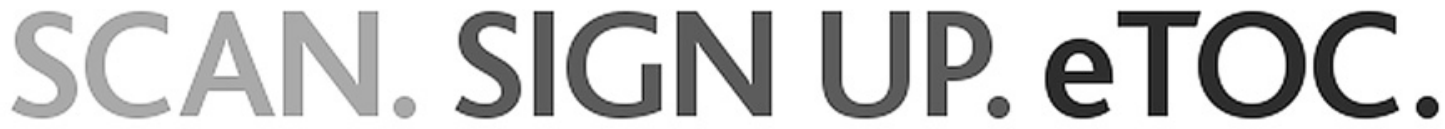 \\ SCAN. SIGN UP.} Utilise our Quick Response code (QR) to sign up for our
electronic table of contents (eTOC) alert.

To make this simple you can sign up now via your Smartphone.

\section{FOLLOWTHESE}

THREE EASY STEPS:

WHY SIGN UP?

A quick and simple way

to keep updated with

developments in

your speciality
1. Downbad a free $Q R$ reader from your handset's app store

2. Hold your Smartphone over the QR code

3. You will then be fonvarded to the eTCC sign up page

To find out more about $Q R$ codes visit group.bmj.com/products/journals/qr-codes 